\title{
FINANCIAL RATIOS FOR EXECUTIVES
}

HOW TO ASSESS COMPANY STRENGTH, FIX PROBLEMS, AND MAKE BETTER DECISIONS

\author{
Michael Rist \\ Albert J. Pizzica
}




\section{Financial Ratios for Executives: How to Assess Company Strength, Fix Problems, and Make Better Decisions}

\section{Copyright @ 2015 by PENHAGENCO LLC}

This work is subject to copyright. All rights are reserved by the Publisher, whether the whole or part of the material is concerned, specifically the rights of translation, reprinting, reuse of illustrations, recitation, broadcasting, reproduction on microfilms or in any other physical way, and transmission or information storage and retrieval, electronic adaptation, computer software, or by similar or dissimilar methodology now known or hereafter developed. Exempted from this legal reservation are brief excerpts in connection with reviews or scholarly analysis or material supplied specifically for the purpose of being entered and executed on a computer system, for exclusive use by the purchaser of the work. Duplication of this publication or parts thereof is permitted only under the provisions of the Copyright Law of the Publisher's location, in its current version, and permission for use must always be obtained from Springer. Permissions for use may be obtained through RightsLink at the Copyright Clearance Center. Violations are liable to prosecution under the respective Copyright Law.

ISBN-13 (pbk): 978-1-4842-0732-1

ISBN-13 (electronic): 978-1-4842-0731-4

Trademarked names, logos, and images may appear in this book. Rather than use a trademark symbol with every occurrence of a trademarked name, logo, or image we use the names, logos, and images only in an editorial fashion and to the benefit of the trademark owner, with no intention of infringement of the trademark.

The use in this publication of trade names, trademarks, service marks, and similar terms, even if they are not identified as such, is not to be taken as an expression of opinion as to whether or not they are subject to proprietary rights.

While the advice and information in this book are believed to be true and accurate at the date of publication, neither the authors nor the editors nor the publisher can accept any legal responsibility for any errors or omissions that may be made. The publisher makes no warranty, express or implied, with respect to the material contained herein.

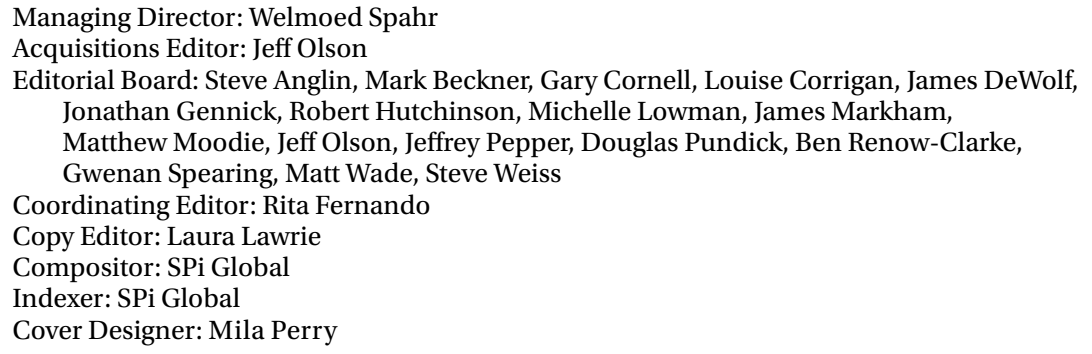

Distributed to the book trade worldwide by Springer Science+Business Media New York, 233 Spring Street, 6th Floor, New York, NY 10013. Phone 1-800-SPRINGER, fax (201) 348-4505, e-mail orders-ny@springer-sbm.com, or visit www.springeronline.com. Apress Media, LLC is a California LLC and the sole member (owner) is Springer Science + Business Media Finance Inc (SSBM Finance Inc). SSBM Finance Inc is a Delaware corporation.

For information on translations, please e-mail rights@apress.com, or visit www.apress.com.

Apress and friends of ED books may be purchased in bulk for academic, corporate, or promotional use. eBook versions and licenses are also available for most titles. For more information, reference our Special Bulk Sales-eBook Licensing web page at www. apress. com/bulk-sales.

Any source code or other supplementary materials referenced by the author in this text is available to readers at Www. apress. com. For detailed information about how to locate your book's source code, go to wwW. apress. com/source-code/. 


\section{Apress Business: The Unbiased Source of Business Information}

Apress business books provide essential information and practical advice, each written for practitioners by recognized experts. Busy managers and professionals in all areas of the business world-and at all levels of technical sophistication-look to our books for the actionable ideas and tools they need to solve problems, update and enhance their professional skills, make their work lives easier, and capitalize on opportunity.

Whatever the topic on the business spectrum-entrepreneurship, finance, sales, marketing, management, regulation, information technology, among others-Apress has been praised for providing the objective information and unbiased advice you need to excel in your daily work life. Our authors have no axes to grind; they understand they have one job only-to deliver up-to-date, accurate information simply, concisely, and with deep insight that addresses the real needs of our readers.

It is increasingly hard to find information-whether in the news media, on the Internet, and now all too often in books - that is even-handed and has your best interests at heart. We therefore hope that you enjoy this book, which has been carefully crafted to meet our standards of quality and unbiased coverage.

We are always interested in your feedback or ideas for new titles. Perhaps you'd even like to write a book yourself. Whatever the case, reach out to us at editorial@apress.com and an editor will respond swiftly. Incidentally, at the back of this book, you will find a list of useful related titles. Please visit us at WWW.apress.com to sign up for newsletters and discounts on future purchases. 



\section{Contents}

About the Authors ........................... vii

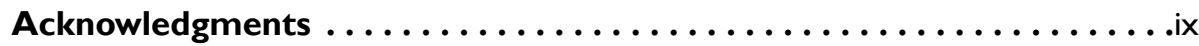

Preface.................................

Chapter I: Ratios Overview....................... I

Chapter 2: Ratios Description ....................

Chapter 3: ABC Company ...................... 07

Chapter 4: Capital Allocation .................... II5

Appendix A: Abbreviations . . . . . . . . . . . . . . . . I 25

Appendix B: Useful Websites . . . . . . . . . . . . . . . I27

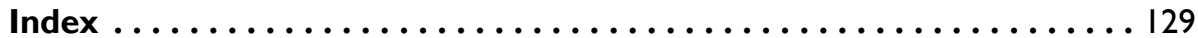





\section{About the Authors}

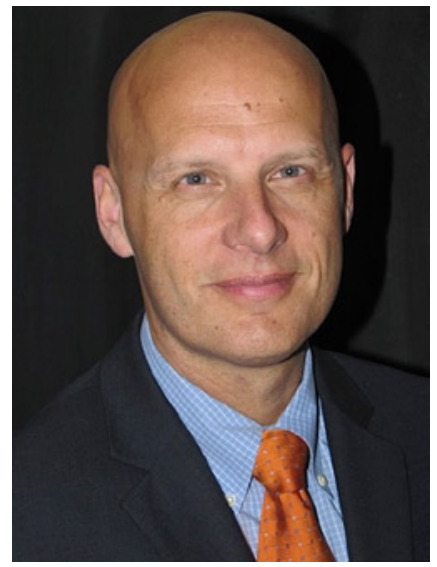

Michael Rist is a senior financial executive with more than 20 years of international operations and business experience within corporate finance for public and privately-held companies and Big 4 public accounting. He has previously been chief financial officer of Mosaica Education, Inc., The Elwing Company, and SES Engineering. $\mathrm{He}$ has worked across the telecommunication, technology, pharmaceutical, industrial manufacturing, and education industries. $\mathrm{He}$ is a Certified Public Accountant and active in a number of professional organizations. Rist holds a BS in Accounting and Finance from Copenhagen Business School and an MBA from the School of Business, Villanova University.

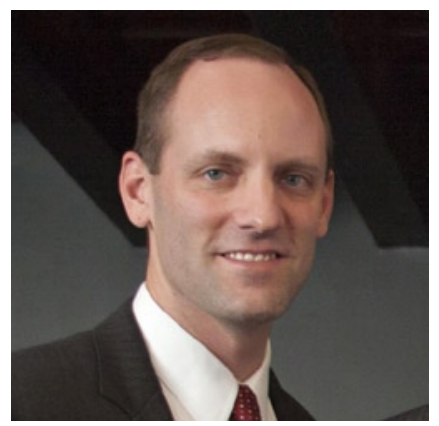

Albert J. Pizzica is an entrepreneur with experience at half a dozen startup companies. $\mathrm{He}$ is currently Vice President of Strategic Programs at American Aerospace and Vice President of Government and Defense Programs at The Elwing Company. He is also the principal at Pizzica Industries LLC, a startup and medium business consulting company. Pizzica's previous experience includes aseptic vaccine manufacturing operations at Merck and as a U.S. Navy officer in various operations roles. Pizzica holds a BS in Mechanical Engineering from Cornell University and an MBA from the School of Business, Villanova University. 



\section{Acknowledgments}

This book reflects the effort, help, and support of many people without whom this book would not have been possible.

Special acknowledgments to our families for making this book come to life.

We would also like to acknowledge all of the individuals who made significant contributions toward the completion of this book, especially Ryan Ohlson, Michael Haller, and George Lemmon, whose detailed review and feedback was such a great help.

We extend our sincere thanks to all of you. 



\section{Preface}

We wrote this book specifically for today's global financial and nonfinancial executives who are looking for an easy-to-use reference book on financial ratios and capital allocation to assist them in operational and strategic decision making. Our aim is to make financial ratios simple and intuitive for everyone to understand.

This book contains over one hundred financial ratios and other calculations commonly used in businesses around the world -including return on investment (ROI), return on assets (ROA), return on equity (ROE), economic value added (EVA), and debt ratio just to name a few.

We have also included a section on what financial and nonfinancial executives need to understand about capital allocation before entering the annual budget meeting or any other business meeting in which capital allocation is discussed. This section describes tools such as net present value (NPV), internal rate of return (IRR), the payback method, and total cost of ownership.

Given that a good understanding of financial ratios, valuation tools, and return on investment calculations are important components of any business system, we set out to create a simplified handbook with short descriptions, calculations, and examples for each of the ratios.

It is important to note that financial analysis is not always black and white. Two experienced finance people can sit down with identical financial information for a company, come up with different ratios, and both be right. Often, financial analysis is more of an art than a science. Accounting and business have their own language and, as with any language, sometimes the same words can have different meanings to different people. Always bear in mind that the particular meaning of a general ratio depends on context.

Consistency is key. Sometimes certain adjustments, such as non-recurring items, are made to specific line items, so as long as you are consistent in doing the same calculation year over year or when comparing companies against each other, your comparisons still have meaning. It may not matter if another accountant, colleague, or business manager gets a different answer; it is the internally consistent comparison and the underlying analysis that matter. 
Microsoft Excel has built-in functions for some of the calculations in this book, such as IRR and NPV. The built-in functions may calculate ratios slightly different than the mathematical formulas do. Again, however, as long as you consistently use the same tool, any disparity between tools may not be analytically significant.

Some ratios are known by multiple names (e.g., the acid test is also known as the quick ratio). For completeness and easy reference, all ratios are duplicated under each name so no back-and-forth page turning is required.

In some of the examples we have also given our readers a sense of the normal ranges of values for specific ratios in various industries.

Remember, the tools described in this book are just that-tools. Whether one carpenter uses a hammer slightly differently than the next carpenter does not matter as long as the job gets done properly. Provided you use the tools in this book consistently and with good business judgment, they can help you make good business decisions. 